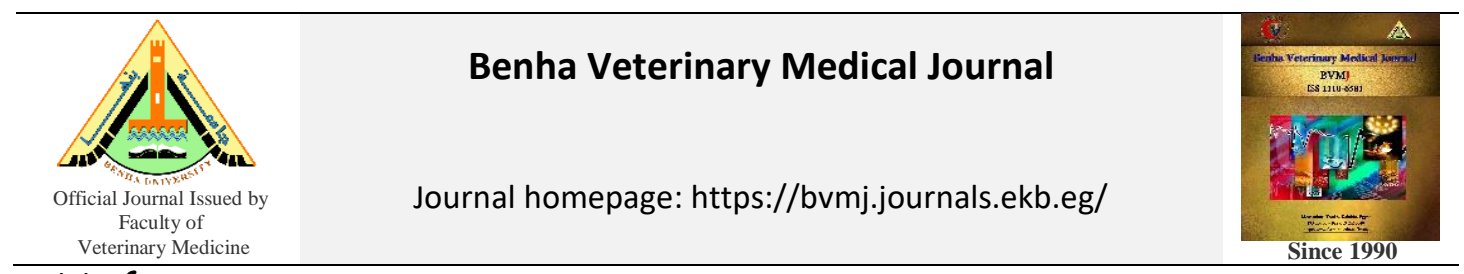

Original Paper

\title{
Degradation effect of Lactobacillus rhamnosus on some heavy metals experimentally inoculated in fish fillet model
}

\author{
Omnia, Y. M. Samir1., Abo-Bakr, M. Edris2., Shima, N. Edris2., Gamal, I. Heikal3 \\ ${ }^{1}$ Veterinarian at Qalubiya Veterinary Directorate, Egypt \\ ${ }^{2}$ Food Hygiene and Control Department, Faculty of Veterinary Medicine, Benha University, Egypt \\ ${ }^{3}$ Food Hygiene Department, Animal Health Research Institute -Tanta branch, ARC, Egypt
}

\begin{tabular}{|c|c|}
\hline ARTICLE INFO & ABSTRACT \\
\hline Keywords & $\begin{array}{l}\text { A total of } 120 \text { samples of fish and shellfish samples represented by Oreochromis niloticus, } \\
\text { Mullus surmuletus, silver carp, shrimp, crab and oyster ( } 20 \text { of each) were collected from } \\
\text { different markets at different localities in Qalubiya Governorate, Egypt. The collected samples }\end{array}$ \\
\hline & were examined for their levels of mercury, lead, and cadmium by atomic spectrophotometer. \\
\hline Fish & The obtained results revealed that $O$. niloticus was the highest contaminated within fish \\
\hline Shellfish & $\begin{array}{l}\text { samples with mean values of } 1.91,1.05 \text {, and } 0.37 \mathrm{mg} / \mathrm{kg} \text {; while oyster was the highest within } \\
\text { shellfish samples with mean values of } 1.53,0.84 \text {, and } 0.29 \mathrm{mg} / \mathrm{kg} \text { for mercury, lead, and }\end{array}$ \\
\hline Lactobacillus rhamnosus & $\begin{array}{l}\text { cadmium, respectively. Advanced experimental work was conducted aimed to assess the } \\
\text { degradation effect of one of Lactobacillus rhamnosus }\left(10^{7} \mathrm{CFU} / \mathrm{ml}\right) \text { on lead and cadmium }\end{array}$ \\
\hline Received 17/05/2021 & levels in experimentally inoculated fish fillet along of 24 hours. Results revealed promising \\
\hline Accepted $17 / 06 / 2021$ & rapid reductions in lead and cadmium levels within $24 \mathrm{hrs}$ of interaction with $L$. rhamnosus, \\
\hline Available On-Line & where lead and cadmium were reduced by 84.3 and $72.0 \%$, respectively. Accordingly, regular \\
\hline 01/10/2021 & $\begin{array}{l}\text { investigation of heavy metals levels in aquatic environment and creatures is recommended, } \\
\text { with strictly recommendation to safe disposal of factory wastes. Furthermore, L. rhamnosus } \\
\text { showed promising diminishing technique to decrease heavy metal accumulation in fish tissues, } \\
\text { where advanced research on its effect on the aquatic environment is recommended. }\end{array}$ \\
\hline
\end{tabular}

\section{INTRODUCTION}

Seafoods have been globally consumed for their nutritional value, along with its high-quality proteins, omega-3, and vitamin B-complex (Özden et al., 2018). In contrast, fish and fish products may cause a serious health hazard along with its consumption because of its high affinity to heavy metals accumulation in their muscle after taking from surrounding environment along their life cycle (Li et al., 2017); marine and fresh water heavy metals contamination can occur through various urbanization, agricultural and industrial unhygienic disposal of their wastes.

Referring to the nature of fish feeding systems, fishes can accumulate heavy metals in their tissues more than surrounding environment as they feed mainly on organic matters, algae and other small organisms which were previously uptake surrounding environmental pollution by heavy metals (Olaifa et al., 2004). The prominent sources of heavy metal contamination are agricultural inputs, domestic and commercial sewage, untreated or partially treated effluents from small and large scale industrial units (Morais et al., 2012); metal electroplating, manufacture and disposal of batteries (Chen et al. 2012), circuit boards, car repair, motor workshops (Singh et al. 2018).

* Corresponding author: dr.omnya@yahoo.com
Seafoods have many elements, which are required for human life at low concentrations, which will be toxic in higher concentrations such as manganese, zinc, and magnesium. Other elements such as mercury $(\mathrm{Hg})$, cadmium $(\mathrm{Cd})$ and lead $(\mathrm{Pb})$ have unknown essential function in life and were toxic even at low concentrations when ingested over a long period; therefore, many health authorities regarded any presence of these elements in foods as a health hazard (Oehlenschläger, 2005).

In the aquatic environment heavy metals are assimilated by fish, since fish is great bioaccumulator, assimilation can occur by ingestion, ion exchange across gills or membrane surface and adsorption by tissues of the fish (Ahmed et al., 2014). It happens in different parts of different fish species due to the varying soluble nature of metals in water, bioavailability and the different habitats, life cycles, nature of feeding, ecology and physiological nature of fish (Anandkumar et al., 2017). High bioaccumulation of heavy metals in the aquatic body can lead to genotoxic damage of aquatic species and high concentrations of heavy metals can have cytotoxic, mutagenic and genotoxic effects on the consumers (Matos et al., 2017).

Numerous studies indicated that lactic acid bacteria (LAB) play an essential role in the body's immunity, detoxification, and elimination of heavy metal residues (Rao, 2009), because of their ability to adhere to- or bind different 
metallic molecules. Previous report by Halttunen et al. (2007) recorded ability of Lactobacillus rhamnosus to chelate many other toxic substances, such as aflatoxin B1, and mutagens from food.

Therefore, many experimental trials have been conducted to eliminate or decrease heavy metal concentrations in food chain to save consumer's health. Consequently, the present study aimed to detect the concentrations of some heavy metals (mercury, lead and cadmium) in the examined fishes and shellfish samples. In addition, assessment of Lactobacillus rhamnosus diminishing effect was performed.

\section{MATERIAL AND METHODS}

\subsection{Collection of Samples:}

A total of 120 samples of Oreochromis niloticus $(O$. niloticus), Mullus surmuletus (M. surmuletus), and silver carb (20 of each) as fishes samples; moreover, shrimp, crab and oyster (20 of each) were collected as shellfishes (20 of each) from different fish markets at different localities in Qalubiya Governorate, Egypt. The collected samples were kept separately in sterile bags and transferred to the laboratory without undue delay.

2.2. Determination of heavy metals:

\subsubsection{Washing procedures (Lars, 2003)}

Glass wares and vessels were washed by deionized water and soaked in hot diluted $\mathrm{HNO}_{3}(10 \%)$ for $24 \mathrm{~h}$, and rinsed several times with deionized water, then dried. Accordingly, all containers were thoroughly washed with deionized water and air-dried in incubator.

2.2.2. Digestion technique (Staniskiene et al., 2006)

Accurately, one gram of each sample was macerated and digested by $10 \mathrm{ml}$ of digestion mixture $(60 \mathrm{ml}$ of $65 \%$ Nitric acid, and $40 \mathrm{ml}$ of $70 \%$ perchloric acid) in screw capped tube, followed by vigorous shaking and heated for $4 \mathrm{~h}$ in water bath at $110^{\circ} \mathrm{C}$ to ensure complete digestion of the samples. Each tube was diluted with deionized water till reach $25 \mathrm{ml}$, then the digest was filtered with Whattman filter paper. The filtrates were collected and kept at room temperature until analyzed for their mercury, lead and cadmium concentrations.

2.2.3. Analysis:

The digest, blanks and standard solutions were aspirated by Atomic Absorption Spectrophotometer and analyzed for their concentrations of such elements.

2.3. Experimental part (effect of Lactobacillus rhamnosus on concentrations of lead and cadmium experimentally inoculated into fish fillets samples):

\subsubsection{Preparation of bacterial suspension}

Lactobacillus rhamnosus strain was enriched in Brain Heart Infusion (BHI) broth and counted by spread cultivation on BHI agar. A volume of the culture broth corresponding to approximately $1 \times 10^{7} \mathrm{CFU} / \mathrm{ml}$ bacteria was centrifuged (500 $\mathrm{rpm}$ for $15 \mathrm{~min}$ ), and the bacterial pellets were washed twice with deionized water (Halttunen et al., 2007).

2.3.2. Binding assay

The bacterial pellet $\left(10^{7} \mathrm{CFU} / \mathrm{ml}\right), 30 \mathrm{mg} / \mathrm{Kg}$ ionic lead, and $10 \mathrm{mg} / \mathrm{Kg}$ ionic cadmium solutions were mixed with fish fillet samples according to Halttunen et al. (2008).

Experimental design

Fish fillet contaminated with metals was served as a control positive group (G1), the test groups represented fish fillets inoculated with $L$. rhamnosus $\left(10^{7} \mathrm{CFU} / \mathrm{g}\right)$ and lead (30 $\mathrm{mg} / \mathrm{kg})(\mathrm{G} 2)$, fish fillets inoculated with $L$. rhamnosus $\left(10^{7}\right.$ $\mathrm{CFU} / \mathrm{g})$ and cadmium $(10 \mathrm{mg} / \mathrm{kg})(\mathrm{G} 3)$, were served as treated groups. The samples were acidified with ultrapure $\mathrm{HNO}_{3}$ (Lars, 2003), and examined at zero, 8-, 16-, and 24hour time points for measuring the free metal by atomic absorption spectrophotometer.

2.4. Statistical analysis:

the obtained results were statistically evaluated by application of Analysis of Variance (ANOVA) test according to Feldman et al. (2003).

Reduction rate $(\%)=\frac{B-A}{A} \times 100$

$\mathrm{B}=$ mean value of the next heavy metal level

$\mathrm{A}=$ mean value of the previous heavy metal level.

Table 1 Operating analyses of different heavy metals conditions

\begin{tabular}{|c|c|c|c|}
\hline Condition & Mercury & Lead & Cadmium \\
\hline $\begin{array}{l}\text { Lamp wavelength } \\
(\mathrm{nm})\end{array}$ & 253.7 & 217.0 & 228.8 \\
\hline $\begin{array}{l}\text { Lamp } \\
(\mathrm{mA})\end{array}$ & 4 & 5 & 4 \\
\hline Slit width (nm) & 0.5 & 1.0 & 0.5 \\
\hline Used gas & $\mathrm{AC} / \mathrm{N}_{2} \mathrm{O}$ & $\mathrm{AC} / \mathrm{A}$ & $\mathrm{AC} / \mathrm{A}$ \\
\hline
\end{tabular}

\section{RESULTS}

It is evident from the results recorded in Table (2) that among the examined fish samples, $O$. niloticus samples revealed the highest contamination with mercury, lead, and cadmium levels ( $\mathrm{mg} / \mathrm{kg}$ ), followed by silver carb and Mullus surmuletus, respectively. Regarding with the examined shellfish, oyster samples were the highest contamination levels, followed by crab, and shrimp, respectively.

Table 2 mean values of different heavy metals levels "mg/Kg" in the examined fish and shellfish samples $(\mathrm{n}=20)$.

\begin{tabular}{|c|c|c|c|c|}
\hline Fish and shellfish & Mercury & Lead & & Cadmium \\
\hline Mullus surmuletus & $1.05 \pm 0.09^{c}$ & $\begin{array}{l}0.49 \\
0.05^{\mathrm{c}}\end{array}$ & \pm & $0.15 \pm 0.01^{\mathrm{c}}$ \\
\hline Silver Carb & $1.49 \pm 0.21^{\mathrm{b}}$ & $\begin{array}{l}0.72 \\
0.06^{b}\end{array}$ & \pm & $0.24 \pm 0.03^{\mathrm{b}}$ \\
\hline $\begin{array}{l}\text { Oreochromis } \\
\text { niloticus }\end{array}$ & $1.91 \pm 0.27^{\mathrm{a}}$ & $\begin{array}{l}1.05 \\
0.11^{\mathrm{a}}\end{array}$ & \pm & $0.37 \pm 0.04^{\mathrm{a}}$ \\
\hline Shrimp & $0.87 \pm 0.06^{\mathrm{d}}$ & $\begin{array}{l}0.36 \\
0.02^{\mathrm{d}}\end{array}$ & \pm & $0.09 \pm 0.01^{\mathrm{d}}$ \\
\hline Crab & $1.22 \pm 0.18^{\mathrm{c}}$ & $\begin{array}{l}0.58 \\
0.04^{\mathrm{c}}\end{array}$ & \pm & $0.20 \pm 0.02^{\mathrm{c}}$ \\
\hline Oyster & $1.53 \pm 0.22^{\mathrm{b}}$ & $\begin{array}{l}0.84 \\
0.07^{\mathrm{b}}\end{array}$ & \pm & $0.29 \pm 0.02^{b}$ \\
\hline
\end{tabular}

Referring to the Egyptian standards for the maximum residual limits as mentioned in Tables (3 to 5), 42.5, 38.3, and $29.2 \%$ of the total examined samples were regarded unfit for human consumption because of exceeding MRL recommended by the Egyptian authorities.

Table 3 Edibility of the examined samples of fish and shellfish based on their levels of mercury $(n=20)$.

\begin{tabular}{|c|c|c|c|c|c|}
\hline \multirow[t]{2}{*}{ Fish and shellfish } & \multirow{2}{*}{$\begin{array}{l}\mathrm{MRL} \\
(\mathrm{mg} / \mathrm{Kg})^{*}\end{array}$} & \multicolumn{2}{|c|}{$\begin{array}{l}\text { Accepted } \\
\text { Samples }\end{array}$} & \multicolumn{2}{|c|}{$\begin{array}{l}\text { Unaccepted } \\
\text { Samples }\end{array}$} \\
\hline & & No. & $\%$ & No. & $\%$ \\
\hline \multicolumn{2}{|l|}{ Mullus surmuletus } & 13 & 65 & 7 & 35 \\
\hline \multicolumn{2}{|l|}{ Silver Carb } & 11 & 55 & 9 & 45 \\
\hline \multirow{2}{*}{\multicolumn{2}{|c|}{$\begin{array}{l}\text { Oreochromis niloticus } \\
\text { Shrimp }\end{array}$}} & 8 & 40 & 12 & 60 \\
\hline & & 15 & 75 & 5 & 25 \\
\hline \multicolumn{2}{|l|}{ Crab } & 12 & 60 & 8 & 40 \\
\hline \multicolumn{2}{|l|}{ Oyster } & 10 & 50 & 10 & 50 \\
\hline \multicolumn{2}{|l|}{ Total } & 69 & 57.5 & 51 & 42.5 \\
\hline
\end{tabular}

* Maximum Residual Limit of Egyptian Standards ES" (2010). 
Table 4 Edibility of the examined samples of fish and shellfish based on their levels of lead $(n=20)$.

\begin{tabular}{|c|c|c|c|c|c|}
\hline \multirow[t]{2}{*}{ Fish species } & \multirow{2}{*}{$\begin{array}{l}\text { MRL } \\
(\mathrm{mg} / \mathrm{Kg})^{*}\end{array}$} & \multicolumn{2}{|c|}{$\begin{array}{l}\text { Accepted } \\
\text { Samples }\end{array}$} & \multicolumn{2}{|c|}{$\begin{array}{l}\text { Unaccepted } \\
\text { Samples }\end{array}$} \\
\hline & & No. & $\%$ & No. & $\%$ \\
\hline Mullus surmuletus & \multirow{7}{*}{0.3} & 14 & 70 & 6 & 30 \\
\hline Silver Carb & & 11 & 55 & 9 & 45 \\
\hline Oreochromis niloticus & & 9 & 45 & 11 & 55 \\
\hline Shrimp & & 15 & 75 & 5 & 25 \\
\hline Crab & & 13 & 65 & 7 & 35 \\
\hline Oyster & & 12 & 6 & 8 & 4 \\
\hline Total & & 74 & 61.7 & 46 & 38.3 \\
\hline
\end{tabular}

Table 5 Edibility of the examined samples of fish and shellfish based on their levels of cadmium $(n=20)$.

\begin{tabular}{|c|c|c|c|c|c|}
\hline \multirow[t]{2}{*}{ Fish species } & \multirow{2}{*}{$\begin{array}{l}\text { MRL } \\
(\mathrm{mg} / \mathrm{Kg}) *\end{array}$} & \multicolumn{2}{|c|}{$\begin{array}{l}\text { Accepted } \\
\text { Samples }\end{array}$} & \multicolumn{2}{|c|}{$\begin{array}{l}\text { Unaccepted } \\
\text { Samples }\end{array}$} \\
\hline & & No. & $\%$ & No. & $\%$ \\
\hline Mullus surmuletus & & 16 & 80 & 4 & 20 \\
\hline Silver Carb & & 13 & 65 & 7 & 35 \\
\hline Oreochromis niloticus & 0.05 & 11 & 55 & 9 & 45 \\
\hline Shrimp & & 17 & 85 & 3 & 15 \\
\hline Crab & & 15 & 75 & 5 & 25 \\
\hline Oyster & & 13 & 65 & 7 & 35 \\
\hline Total & & 85 & 70.8 & 35 & 29.2 \\
\hline
\end{tabular}

Referring to the demonstrated results in Tables (6 and 7), addition of $L$. rhamnosus culture $\left(10^{7} \mathrm{CFU} / \mathrm{ml}\right)$ revealed rapid promising diminishing effect on lead and cadmium levels as they were reduced by 84.3 and $72 \%$ within $24 \mathrm{~h}$ of the incubation; furthermore, higher degradation level on lead were recorded than cadmium levels in experimentally inoculated fish fillet model.

Table 6 Effect of L. rhamnosus culture $\left(10^{7} \mathrm{CFU} / \mathrm{g}\right)$ on the levels of lead experimentally inoculated to fish fillets $(30 \mathrm{mg} / \mathrm{Kg})$.

\begin{tabular}{llll}
\hline $\begin{array}{l}\text { Storage } \\
\text { time }\end{array}$ & $\begin{array}{l}\text { Control } \\
(\mathrm{mg} / \mathrm{Kg})\end{array}$ & $\begin{array}{l}\text { L. rhamnosus } \text { Treated group } \\
(\mathrm{mg} / \mathrm{Kg})\end{array}$ & $\begin{array}{l}\text { Reduction } \\
\%\end{array}$ \\
\hline Zero time & 30 & 30 & ------ \\
\hline 8 hours & 30 & 9.2 & 69.3 \\
\hline 16 hours & 30 & 5.8 & 80.7 \\
\hline 24 hours & 30 & 4.7 & 84.3 \\
\hline
\end{tabular}

Table 7 Effect of L. rhamnosus culture $\left(10^{7} \mathrm{CFU} / \mathrm{g}\right)$ on the levels of cadmium experimentally inoculated to fish fillets $(10 \mathrm{mg} / \mathrm{Kg})$.

\begin{tabular}{llll}
\hline $\begin{array}{l}\text { Storage } \\
\text { time }\end{array}$ & $\begin{array}{l}\text { Control } \\
(\mathrm{mg} / \mathrm{Kg})\end{array}$ & $\begin{array}{l}\text { L. rhamnosus } \\
\text { Treated group } \\
(\mathrm{mg} / \mathrm{Kg})\end{array}$ & Reduction \% \\
\hline Zero time & 10 & 10 & ---- \\
\hline 8 hours & 10 & 4.9 & 51.0 \\
\hline 16 hours & 10 & 3.6 & 64.0 \\
\hline 24 hours & 10 & 2.8 & 72.0 \\
\hline
\end{tabular}

\section{DISCUSSION}

Heavy metals are hazardous contaminants in food and environment. These are non-biodegradable with long biological half-lives (Heidarieh et al., 2013). So, the present study was carried out to survey and investigate the concentrations $(\mathrm{mg} / \mathrm{kg})$ of mercury, lead and cadmium in some commercially present fish and shellfishes in the Egyptian markets represented by (Mullus surmuletus, silver carb, O. niloticus, shrimp, crab, and oyster).

Regarding Table (2), the obtained results of mercury were higher than those obtained by El-Nahas $(2015)(0.46 \mathrm{mg} / \mathrm{kg}$ in $O$. niloticus), Fatema et al. (2015) $(<0.03 \mathrm{mg} / \mathrm{kg}$ of the examined shrimp samples), El-Said (2016) $(0.037 \mathrm{mg} / \mathrm{kg}$ in O. niloticus), and Helmy et al. (2018) (1.29, 0.95, 1.37, 1.14, and $0.73 \mathrm{mg} / \mathrm{kg}$ of $O$. niloticus, $M$. cephalus, oyster, shrimp, and crab samples, respectively).

Mercury can accumulate in human body through consumption of fish and other marine creatures. Neurotoxic effect of mercury toxicity, particularly in developing organisms, fetuses, infants, and young children generally are more sensitive than adults to the neurological effects (Agusa et al., 2005).

In regard to the obtained results of lead concentrations, they were nearly similar with those recorded by Fatema et al. (2015) (ranged from 0.108 to $0.87 \mathrm{mg} / \mathrm{kg}$ in shrimp samples collected from Kobadak river, Bangladish), while higher than those recorded by El-Said (2016) $(0.24 \mathrm{mg} / \mathrm{kg}$ in $O$. niloticus samples), Hadeed et al. (2017) (0.18 mg/kg Pagrus bayad), Helmy et al. (2018) $(0.53,0.56,0.48$, and $0.4 \mathrm{mg} / \mathrm{kg}$ of $O$. niloticus, oyster, shrimp, and crab samples, respectively); but also, they were lower than those recorded by Ilgar (2016) (was $5.57 \mathrm{mg} / \mathrm{kg}$ in $S$. pilchardus), and Mehouel et al. (2019) (2.13 mg/kg in sardine).

High doses of lead causes chronic toxicity that includes renal, GIT, hematological and neuromuscular disorders. The main sings of lead intoxication in children are disability of learning and behavior abnormalities. In contrast, the principal sings of lead intoxication in adults are abdominal pain, kidney damage, headache, loss of memory, weakness, male reproductive impairment and tremors in extremities. Severe problems as dysfunction in nerve, joints and muscles, loss of memory, heart, bone and renal disorders occur due to the exposure to highly doses of lead than permissible limits (Environmental Working Group, 2010).

Referring to the documented results of cadmium levels, nearly similar results were recorded by Sohsah (2009) $(0.26$ $\mathrm{mg} / \mathrm{kg}$ in $O$. niloticus). Lower results were recorded by Fatema et al. (2015) (ranged from ND to $0.04 \mathrm{mg} / \mathrm{kg}$ of the examined shrimp samples), El-Said (2016) $(0.051 \mathrm{mg} / \mathrm{kg}$ in O. niloticus), Helmy et al. (2018) $(0.19,0.22,0.15$, and 0.12 $\mathrm{mg} / \mathrm{kg}$ of $O$. niloticus, oyster, shrimp, and crab samples, respectively). and Gawish and Hosni (2017) (0.0492 and $0.0366 \mathrm{mg} / \mathrm{kg}$ in sardine and morgan, respectively). While higher results were recorded by Mehouel et al. (2019) (0.55 $\mathrm{mg} / \mathrm{kg}$ in sardine samples), and Hadeed et al. (2017) (0.14 $\mathrm{mg} / \mathrm{kg}$ in Pagrus bayad samples). Moreover, Omobepade et al. (2020) (0.003 and $0.025 \mathrm{mg} / \mathrm{kg}$ for cadmium and lead concentrations in shrimp samples, respectively).

Cadmium is a heavy metal that accumulates in the body resulting in brain damage, astroglial toxicity (Im et al., 2006). Chronic toxicity of cadmium induces bone abnormalities and kidney impairment, while acute toxicity results in vomiting, gastritis, and diarrhea. Furthermore, lung cancer is reported due to inhalation of cadmium (ATSDR, 2008).

Statistical analyses of the recorded results revealed significant differences $(P \geq 0.05)$ between the examined results; where $O$. niloticus and oyster were the predominant highly contaminated samples in the examined fishes and shellfishes, respectively that may be caused by the highly 
contaminated surrounding environment and/or bioaccumulation process based on the age of the collected samples.

The recorded variations between the obtained results and the other records may be attributed to the difference in the localities of sample's collection, age of fishes as a significant factor in bioaccumulation process, and types of the examined fishes.

An experimental study was conducted to investigate the lead and cadmium levels degradation under the effect of $L$. rhamnosus in fish fillet model. Results as tabulated in Tables (6 and 7) showed a great diminishing effect in lead and cadmium levels, respectively.

Generally, potential significant reduction in the prevalence of genotoxicity and hepatotoxicity rat model by cadmium after inoculation of L. rhamnosus (Jama et al., 2012). The diminishing interaction effect of LAB with heavy metals can be attributed to its ability to bind with the metals intra- or extracellular by biosorption the passive no metabolically mediated binding process of metal ions to the LAB cell wall, so preventing any harmful interaction in the host cell (Mrvcic et al., 2012).

\section{CONCLUSION}

As conclusion, $O$. niloticus and oyster were the predominantly contaminated samples with heavy metals residues within the examined fish and shellfish samples, respectively. Detection of heavy metals in such toxic concentrations in the examined samples possess a potential risk to the consumers, so regular investigation of heavy metals levels in aquatic environment and creatures is recommended, with strictly recommendation to safe disposal of factory wastes. Furthermore, L. rhamnosus showed promising diminishing technique to decrease heavy metal accumulation in fish tissues, where advanced research on its effect on the aquatic environment us recommended.

\section{REFERENCES}

1. Agusa, T., Kunito T., Iwata, H., Monirith, I., Tana T.S., Subramanian, A. and Tanabe, S. (2005): Mercury contamination in human hair and fish from Combodia. Levels specific accumulation and risk assessment. Environ. Pollut. 134: 79-86.

2. Ahmed, M.K., Parvin, E., Islam, M.M., Akter, M.S., Khan, M.S., Al-Mamun, M.H. (2014): Lead and cadmium induced histopathological changes in gill, kidney and liver tissues of freshwater climbing perch Anabas testudineus (Bloch, 1792). Chem. Ecol., 30: 532-540 (9 pages).

3. Anandkumar, A., Nagarajan, R., Prabakaran, K. and Rajaram, R. (2017): Trace metal dynamics and risk assessment in the commercially important marine shrimp species collected from the Miri coast, Sarawak, East Malaysia. Reg. Stu. Mar. Sci., 16: 79-88 (10 pages).

4. ATSDR "Agency for Toxic Substances and Disease Registry" (2008): Toxicological profile for Hexachlorocyclohexane. Atlanta, GA: U.S. Department of Health and Human Services, Public Health Service, http://www.atsdr.cdc.gov.

5. Chen, C.W., Chen, C.F. and Dong, C.D. (2012): Distribution and accumulation of mercury in sediments of Kaohsiung River mouth, Taiwan. APCBEE Procedia, 1: 153-158.
6. Egyptian Organization for Standardization "ES" (2010): Maximum Levels for certain contaminants in foodstuffs. No 7136/2010. Egyptian Standards, Ministry of Industry, Egypt.

7. El- Said, M.S.M. (2016): Heavy metal residues in imported and local fishes in Egypt. Thesis, Master of Vet. Sci. (Meat Hygiene), Beni-Suef Univ., Egypt.

8. El-Nahas, S.B. (2015): Heavy metal residues in freshwater fish.M. V. Sc., Thesis. (Meat Hygiene) Fac. Vet. Med. Benha. Univ., Egypt.

9. Environmental Working Group "EWG" (2010): Lead compounds. Retrieved November 5, 2010, from http// www.ewg: org/ chemindex/ term/ 455.

10. Fatema, K., Naher, K., Choudhury, T.R., Islam, M.A., Tamim, U., Hossain, S.M., Islam, S.M.A. and Ali, M.P. (2015): Determination of toxic metal accumulation in shrimps by atomic absorption spectrometry (AAS). J. Environ. Anal. Chem., 2(3): 140-147.

11. Feldman, D., Ganon, J., Haffman, R. and Simpson, J. (2003): The solution for data analysis and presentation graphics. $2^{\text {nd }}$ Ed., Abacus Lancripts, Inc., Berkeley, USA.

12. Gawish, M.M. and Hosni, I.M. (2017): Assessment of some heavy metals in the economic fishes in Hail market, Kingdom of Saudi Arabia. Int. J. Curr. Res. Biosci. Plant Biol., 4(2): 7-15.

13. Hadeed, H.A., Aljetawi, A.A. and Alhemmali, E.M. (2017): Determination of some essential and toxic heavy metals in liver tissue for Marine fish species from cost of Misurata, Libya. $1^{\text {st }}$ National Conference on Marine and Ground water pollution $\left(1^{\text {st }}\right.$ NCMGP, 2017).

14. Halttunen T., Collado, M., El-Nezami, H., Meriluoto, J., Salminen, S. (2008): Combining strains of lactic acid bacteria and heavy metal removal efficiency from aqueous solution. Letters Appl. Microbiol. 46:160 165.

15. Halttunen, T., Salminen, S. and Tahvonen, R. (2007): Rapid removal of lead and cadmium from water by specific lactic acid bacteria. Inter. J. Food Microbiol., 114: 30-35.

16. Heidarieh, M., Maragheh, M.G., Shamami, M.A., Behgar, M. and Ziaei, F. (2013): Evaluate of heavy metal concentration in shrimp (Penaeus semisulcatus) and crab (Portunus pelagicus) with INAA method. Springer plus, 2: 72-76.

17. Helmy, N.A., Hassan, M.A., Hassanien, F.S. and Maarouf, A.A. (2018): Detection of heavy metals residues in fish and shellfish. Benha Vet. Med. J., 34(2): $255-264$

18. Ilgar, R. (2016): A study on heavy metal content of Sardine (Sardina pilchardus) caught in the Dardanelles. Journal of Geography and Geology., 8 (3): $35-41$.

19. Im, J.Y.; Paik, S.G. and Han, P.L. (2006): Cadmiuminduced astroglial death proceeds via glutathione depletion. J. Neurosci. Res., 83(2): 301-310.

20. Jama, A.M., Dragana, M.C., Kolarevic, S., Sinisa, F.Đ. and Jelena, K. (2012): Protective effect of probiotic bacteria against cadmium-induced genotoxicity in rat hepatocytes in vivo and in vitro. Arch. Biol. Sci., Belgrade, 64 (3): 1197-1206.

21. Lars, J. (2003): Hazards of heavy metal contamination. British Med. Bull. 68: 167-182. 
22. Li, J., Sun, C., Zheng, L., Jiang, F., Wang, S., Zhuang, Z. and Wang, X. (2017): Determination of trace metals and analysis of arsenic species in tropical marine fishes from Spratly islands. Mar. Pollut. Bull., 122(1-2): 464469.

23. Matos, L.A., Cunha, A.C.S., Sousa, A.A., Maranhão, J.P.R., Santos, N.R.S., Gonçalves, M.M.C., Dantas, S.M., Sousa, J.M., Peron, A.P., Silva, F.C., Alencar, M.V., Islam, M.T., Aguiar, R.P., Melo-Cavalcante, A., Bonecker, C.C. and Junior, H.F.J. (2017): The influence of heavy metals on toxicogenetic damage in a Brazilian tropical river. Chemosphere, 185: 852-859.

24. Mehouel, F., Bouayad, L., Hammoudi, A.H., Ayadi, O. and Regard, F. (2019): Evaluation of the heavy metals (Mercury, Lead and Cadmium) contamination of Sardine (Sardina pilchardus) and sword fish (Xiphia sgladius) fished in three Algerian coasts. Vet. World, EISSN: 2231- 0916 (12): 7-11.

25. Morais, S., Costa, F.G. and Pereira, M.L. (2012): Heavy metals and human health. In: J. Oosthuizen (Ed.), Environmental health - emerging issues and practice (pp. 227-246). London: Intech Open Limited.

26. Mrvcic, J., Stanzer, D., Solic, E. and Stehlik-Tomas, V. (2012): Interaction of lactic acid bacteria with metal ions. opportunities for improving food safety and quality. World J. of Microbiol. and Biotechnol., 28 (9): 2771-2782.

27. Oehlenschläger, J. (2005): Identifying heavy metals in fish. In: Safety and Quality Issues in Fish Processing. Ed: Bremner, H.A. WoodheadPublishing Limited and CRC Press LLC. pp. 95-108

28. Olaifa, F., Olaifa, A., Adelaja, A. and Owolabi, A. (2004): Heavy metal contamination of Clarias gariepinus from a lake and fish farm in Ibadan, Nigeria. Afric. J. Biomed. Res., 7: 23-27.

29. Omobepade, B.P., Ademola, M.A., Adefemi, O.A., Eunice, M.O., Tolulope, O.A., Jeremiah, O.J., Kemisola, M.O., Onyinye, S.O., Michael, A.F., Segun, M.A. and Akinola, M.A. (2020): Heavy metal concentration in white shrimp Nematopalaemon hastatus and their associated ecological and health risk in the Nigerian continental shelf. Egypt. J. Aqua. Biol. And Fisher., 24(2): 301-316.

30. Özden, Ö., Erkan, N. and Kaplan, M. (2018): Toxic metals and omega-3 fatty acids of blue fin Tuna from aquaculture: Health risk and benefits. Expo. Hlth., 110.

31. Rao, K.S. (2009). Free radical induced oxidative damage to DNA: relation to brain aging and neurological disorders. India. J. Biochem. Biophysics, 46: 9-15.

32. Singh, D.V., Bhat, J.I., Bhat, R.A., Dervash, M.A. and Ganei, S.A. (2018): Vehicular stress a cause for heavy metal accumulation and change in physico-chemical characteristics of roadside soils in Pahalgam. Environ. Monitor. Assess., 190(6): 353-359.

33. Sohsah, M.A.M. (2009): Studies on some heavy metal residues in freshwater fish with special reference to water environmental pollution. Thesis, Ph.D. of Vet. Sci. (Meat Hygiene), Benha Univ., Egypt.

34. Staniskiene, B., Matusevicius, P., Budreckiene, P. and Skibniewska, K.A. (2006): Distribution of heavy metals in tissues of freshwater fish in Lithuania. Polish J. Environ. Studies, 15(4): 585-591. 